\title{
SYMPTOMS OF YOUTH SOCIAL MALADJUSTMENT. NEW TENDENCIES
}

\author{
ARKADIUSZ KAMIŃSKI \\ Faculty of Pedagogy, University of Wroclaw, \\ ul. Dawida 1, 50-527 Wrocław, Poland \\ E-mail adres: arkadiusz.kaminski@uwr.edu.pl
}

\begin{abstract}
The contemporary socioeconomic transformations in a fundamental way impinge on the shift of displaying social maladjustment among young people. The forms of social activities of, the adolescents undergo a transformation along with dynamics of the current social progress. Some youth, as a consequence of their behaviour and state of demoralization, become subjects of judicial proceedings and sanctions, such as residential rehabilitation or correctional centers. In order to capture the tendencies of youth's social maladjustment a behavior research was carried out among 120 pupils sentenced by court to a youth care center. The author has undertaken a research indicating, the evolving modes of the youth's social functioning and the diagnosed symptoms of their social maladjustment have been captured and researched by the author of this paper.
\end{abstract}

Key words: social maladjustment, social changes, posts for juveniles, disorder of behavioral disorder, demoralization, addictions.

\section{INTRODUCTION}

The world of the second decade of the twenty first century is characterized by further pushed dynamics of social processes. They arise from the processes of globalization, digitalization, the migration of population and the crisis of value as well as the search for new ideas and their solutions. The crisis of values affects the western world, but as it also incorporates the moral crisis, it concerns the poor countries as much as the rich ones. Having stated that, one should emphasize the fact that a crisis does not need to equal a loss, for a crisis can become the beginning of something new. It is necessary, therefore, to seek a new paradigm of preventing social threats and pathologies (Jaworska, 2008, p. 34).

The phenomena of social maladjustment largely affect the younger generation and in this aspect they are a matter of great concern and far reaching consequences, as youth determines the rise and formation of the next generations. It is among this group that the first symptoms of social crises are displayed, including behaviour diverging from social norms. Such 
behaviour remains at variance with the positive aspirations of youth, their life aims and aspirations. A failure to conform to social norms contributes to the emerging of wide groups of individuals demonstrating symptoms of social maladjustment, displaying noticeable weakening of volitional factors and unharmonious emotional development. These individuals are prone to changeable moods and suffer from concentration problems. Socially maladjusted children and teenagers usually lack interests. They reluctantly undertake any challenges that require effort or discarding of their own desires, and divergence from social norms and aspirations. Consequently, some violate the established legal settlement and become subjects of judicial proceedings under the Act on Proceedings in juvenile cases of the 28th of October 1982 (Ustawa z 26 października 1982 r. o postępowaniu w sprawach nieletnich, 1982). Delinquent behaviour remains the most distinctive symptom of social maladjustment, not only when it comes to teenagers, but children as well. They engage in delinquent behaviour within the context of a peer group, i.e. being influenced by peer approval of delinquent behaviour or peer pressure for deviance. Such behaviour is also associated with a high probability of inappropriate and antisocial attitude. Having a police record or having been convicted establishes a real barrier in further education as well as professional development. Nevertheless, more and more frequently it is becoming a reason to be proud of, one's distinguishing quality, an outstanding distinctive individual in their peer group and hoisting of their positions (Kryska, 2014, p. 207).

Juvenile probationers, can be subjected to various sanctions, such as rehabilitation and non-residential or residential correctional programs. Nevertheless, it ought to be kept in mind that any official intervention is to be pursued primarily in the overall interest of the young person and guided by achieving positive developments in their personality and behaviour. Measures should be taken to provide families with the opportunity to fulfill parental roles and obligations as regards child development and child care, taking into consideration the social interest (Ustawa z 26 października 1982 r. o postępowaniu w sprawach nieletnich, 1982, art. 3). Therefore, no young probationer should be subjected to degrading punishment measures; the goal should be to alter their behaviour thus striving for their positive social functioning We have to, as a consequence, aim at changing their forms of behaviour from social maladjustment to socially approved attitude. Unfortunately, in the dynamically changing society the notion of a pattern and a norm undergoes a profound transformation, and so changes, the range of defining the very phenomenon of social maladjustment. In order to capture the tendencies of youth's social maladjustment a behavior research was carried out among 120 pupils sentenced by court to a youth care center. 


\section{THE PHENOMENON OF SOCIAL MALADJUSTMENT}

Social maladjustment as a phenomenon is a field of interest to different representatives of research such as psychologists, psychiatrists, pedagogues and sociologists. It depends on the different attitudes and opinions relating to aetiology, demonstrations and justification of social maladjustment, it is variously interpreted, and in relationship with this and the terminology is not applied compatibly. Instead of the term social maladjustment are used changeable definitions: morally untidy - as an effect of environmental aberration, disturbed in one's behaviour, untidy, derailed or morally menaced - referring not only to a child, but and also to the environment, in which it lives.

Despite this phenomenon, of maladjustment introduced in Poland a few years ago by Maria Grzegorzewska it still stays current in its concept. She affirmed, that the phenomenon of impossible adaptation of teenagers should be treated as a general social disaster. She also thought, that it is extremely difficult to express clearly the causes as well as the geographical range of this phenomenon (Grzegorzewska, 1964, p. 317), and it concerns mainly these developmental periods, such as childhood and the teenage years. Aiming at the essential question M. Grzegorzewska claimed, that under term of maladjusted youth should be understood "[...] team of all juveniles in need of special educational methods, social, medically - psychological and medical in relation with tutors which have to turn to special methods [...]" (Grzegorzewska, 1964, pp. 317-318). By observing today's society, we can state that little has changed in this fundamental aspect. The causes of social maladjustment, continuing the thought of M. Grzegorzewska (1964, p. 318), it could be: orphanage, homelessness, moral threats, crime, up to every form of mental handicap. However, Lesław Pytka (1997, p. 84) accepts two categories of disorders. In the first, he includes children and youth that are socially maladjusted, which as a result of internal disorders or negative environmental interactions display disorders in behaviour. In the second, he adds menaced maladjusted adolescents. In this category the cause of disorders is the negative influence of family, peer groups as well as environmental factors. According to L. Pytka the coefficient is discordant behaviour with recognized conducted principles, the system of values or also the expectations of the parents, school or different environmental principles of social opinions that create rules of social life. Consciousness for young people is not a companion, but disturbed principles of social behaviour, that at a certain stage they disorganize the social system and become a psychical and physical threat for different members of a given community. Social maladjustment is defined through symptoms of behaviour where the numeral can be described in the range from three to fifteen. Including (Pytka, 1997, p. 85): the abuse of alcohol, drug addiction, toxin obsession, suicide and suicide attempts, prostitution and promiscuity, running away from home, truancy, social parasitism, participation in uncultural gangs, notorious lies, vulgarity, school laziness, disobeying 
internal regulations and rules of the school, unable to concentrate, fear, conflicts with teachers or intensive conflicts with peers.

The phenomenon of social maladjustment is more widely defined by Czesław Cekiera with reference to the psychical health of an individual. Symptoms of social maladjustments are considered (Cekiera, 1979, p. 5): shouting fits, crying or inadequate anger to active stimuli, physical awareness or psychical on chosen stimuli; emotional hypererethism; insomnia as well as frequent conscious dreams; the lack of appetite or excessive voracity; fleeing from illnesses; regress to forms of characteristic behaviour for earlier developmental stages; fears and feeling threatened; feeling depressed, apathy, isolation; helplessness and incapability; disrespectful relation to home duties and school; negligence in learning - negative relation to school; notorious lies and fraud; truancies and running away from home; thefts; aggressions towards people and animals; smoking cigarettes, alcoholism, the abuse of medicines and narcotics; hooliganism and vandalism; participation in informal groups; the modifications of the body (tattoos); a parasitic mode of life as well as the avoidance of criticism. Such a wide understanding of the phenomenon of social maladjustment and expansion of unacceptable social behaviour with various behaviour characterises the present functioning of individuals, and in peculiar youth. It seems problematic enough and it can contribute to the assumption of the definition of social maladjustments to wide social groups. Therefore, it would seem advisable to also treat the general medical perspective of the problem. In the medical diagnosis of behaviour where the symptoms can be recognized as a social maladjustment are defined as disorders of behaviour. According to the American classification of psychical disorders DSM IV disorders of behaviour are "repeating themselves and have a lasting patterns in behaviour, where basic principles of others are violated as well as the primary for a given age of norms and regulation symptoms in the last few months" (Selingman, Walker, \& Rosenhan, 2003, p. 376).

However, on the basis of sociology and pedagogy, the social maladjustment is seen as a disorder in the process of society (socialization) the symptoms are relatively durable and repeat in inadequate reactions to norms and social examples. The disturbing functioning of individuals is fulfilled though roles that are influenced by various different disorders that are caused by internal and external factors conditioning the development. It is therefore closely related with the lack of psychophysical homeostasis in life of the individual and not feeling secure.

The common element to different disciplinary definitions of social maladjustment is persuasion. The demonstrative phenomena of maladjusted youth in their behaviour remains in contradiction with norms, values and the socially recognized expectations. The negative consequences of this behaviour on the micro social scale which threaten the physical safety and the specific psychical individuals and on the macro social scale disorders of the functioning of the social system. 
Nevertheless, from the formally legal point of view the phenomenon of social maladjustment is not so wide and has become unambiguously formulated. Already mentioned the basic regulated legally related minors to the settlement law of 26 October 1982 r. (Ustawa z 26 października 1982 r. o postępowaniu w sprawach nieletnich, 1982, art. 4, § 1) the legislator quite clearly states that the symptoms being the definition of juvenile demoralization, which is the impingement on the principles of social living together; commissioning the acts the law forbids; systematic annulations from school duties or professional education; usage of liquor or other agents that alter consciousness; prostitution; vagabondage as well as being part of criminal groups.

\section{THE INTERACTION APPLIED TO TEENAGERS THAT ARE SOCIALLY MALADJUSTED}

In Poland for minors there exist centers that are educationally reformative because minors should not be convicted. This looks a bit different from the perspective of the minor and his family who can see the center as a repression in relation to themselves. Especially, since some centers aim to achieve positive intentional education and this can be followed by definite inconveniences. Because of this one should aim at accepting the juvenile, their family and the given court decision and understand their needs of implementing hope of co-operation from their side. The aim in relation to the actions of the juvenile is to repair the educational process and at the same time achieve changes in behaviour, which depends on the resignation of accepted social behaviour as well as the assimilating socially accepted behaviour. Because of this, centers should adapt the possibility of psychical youth and their needs (which should be diagnosed correctly) as well as use their possibilities that create the surroundings of the juvenile. The school, social organizations and different institutions give psychological, pedagogical, sport and educational help. The family environment of the minor should be taken into consideration, as it could turn out that they need therapy or change (Klaus, 2009, p. 265).

In accordance with the Polish law in the case of a juvenile the court can apply a whole scale of remedies applied to prevent the fight against demoralization and crimes of the juvenile, such as: to reprimand, obligate to a definite conduct, repair the damage which is already done; establish responsible supervision of parents or a guardian; establish supervision of a youth organization or different social organization and an institution from work or a person who is reliable that would be a guarantee for the juvenile; the use of a curator supervision; the referral to a curator centre and also to a social organization or an institution that deals with work of juveniles having an educational character, therapeutic or training; a sentence about locating in a supplementary family in a suitable educational care post; a sentence about locating in a reformatory (Ustawa z 26 października 1982 r. o postępowaniu $w$ sprawach nieletnich, 1982, art. 6). 
The most severe remedy according to what we have read, which we can apply in terms of the minor is to place him in a reformatory. This can be applied when different remedies on the juvenile have proven to be ineffective. Rehabilitation of juveniles in reformatories is not the best solution, as in this case of minors who are sentenced to attend an artificially created closed environment which is isolated from the natural environment, which can exert an unfavourable influence. One should ask oneself what should be done with some of the most demoralized youth that committed the most serious offences?

If the court states that the juvenile is mentally handicapped, has mental disorders, has other physical disorders or is addicted to alcohol or other agents it can aim at introducing intoxication, the court can apply the so called educational-healing in terms of directing them in a psychiatric hospital or other healing institution. If there is a need of assuring the juvenile only educational care, the court can sentence them to a suitable educational care post, and in this case when the juvenile is mentally handicapped to a large degree and only requires care - to a home with social help (Ustawa z 26 października 1982 r. o postepowaniu w sprawach nieletnich, 1982, art. 12).

A post with a specific character (taking into consideration the character of locating the minor) is the youth centre of sociotherapy. The principles of its functioning has changed together with the amending acts about the conduct in juvenile cases (Obwieszczenie Ministra Sprawiedliwości..., 2002). The change depends on the divided way of managing youth centers of sociotherapy and educational youth centers. The current rules in this range gave a wider choice allowing sentences in terms of juveniles at educational centers in the range of directing them to different posts of the educational system, being a youth center of sociotherapy.

The legislator presumed, that such a solution is inadequate, because the reactions in terms of pupils at a youth centres of sociotherapy is voluntary therapy and in close co-operation with the therapist. In connection with this, the family courts can not state the direction of the educational youth centre of sociotherapy in terms of the menaced juvenile that is socially maladjusted, what they could do until 31 December 2011, only placing them in youth educational centers. Pupils at youth centers of sociotherapy are accepted on the exclusive basis of an application by parents or legal guardians. This is connected with the different specifics and aims of the functioning of youth centers of sociotherapy and educational youth centers, as well as the different ways of interactions of pupils at both posts. At youth centers of sociotherapy they participate in therapeutic lessons as well as specifically organized set lessons in psychological-pedagogical aimed at rehabilitation. However, for pupils from resocialization educational centers there are lessons of resocialization and other specialist lessons, where for the handicapped there are rehabilitation and resocialization lessons.

The regulations clearly define, that being placed at a resocialization post such as the educational youth centre is the final educational measure which 
should be applied only after all of the other different legal possibilities of preventing juvenile demoralization have been used. Therefore locating the juvenile in an educational centre is the last possibility of guarding the minor before directing to a reformatory.

The basic tasks of an educational youth centre are to first of all abolish every cause and symptom of social maladjustment which is harmful to both the surroundings, as well as the individual, preparing the juvenile to renew social adaptation, applied for professional work as well as life which is socially compatible and has legal valid norms and principles. In reflexion of the regulation of the Minister of National Education the tasks of these centers put into practice: organize didactic activities, preventative - educational, therapeutic and resocialization enabling them to obtain the correct life facilitating skills that will make it easier for the correct functioning of a family and social environment, help in planning an educational and professional career, with regard to the possibility and the pupils' interests, giving help to the parents (the legal guardians) in range of improving indispensable skills in supporting their children's development, in the range of potential possibilities as well as the avoidance of risky behaviour (Rozporzadzenie Ministra Edukacji Narodowej..., 2011).

The educational youth centers assure pupils twenty four hour care, and the basic form of organisational work is an educational group. The centers have a homogeneous character, this means that there is a division into groups, sex, age, as well as the level of school knowledge. Schools function in them, in which both the program as well as the didactic work is adapted to their intellectual level and social immaturity.

\section{SYMPTOMS OF SOCIAL MALADJUSTMENT AMONG MINORS}

Taking into consideration the predominant role of the number of pupils directed in the Polish system of rehabilitation that at present play in educational youth centers, the juveniles at these posts make up a research group with many incidents, which serve in tendency terms to social maladjustment of children and youth.

In the research conducted by Aneta Paszkiewicz in the years 2007- 2011 on a group of pupils of such posts, they appeared to display social maladjustment which was taken into account (Paszkiewicz, 2012, pp. 155-156): truancies, contacts with a demoralized environment, aggression, disorderly offences, thefts, many hours of wandering without control in the streets, running away from home, smoking cigarettes, drinking liquor, abusing medicine and narcotics, being part of pseudo fan clubs, taking out from the house valuable objects and money as well as injuring themselves. The most frequent symptoms of social maladjustment, which appeared in the research were truancies. More than once, truancies were accompanied by different symptoms of social maladjustments having a relationship with the school environment (Paszkie- 
wicz, 2012, p. 155): disrespectful relation to school duties, not putting effort into learning, not keeping school note books, disrespecting each and every effort undertaken by the school, educational difficulties at school, disturbing and making it impossible for teachers to teach a lesson, arrogant behaviour towards the teacher as well as the self-willed behaviour at the lesson. Similar symptoms of behaviour were displayed in different research and the statistics conducted in the period of 2002-2007 by the Methodical Centre of Psychological - Pedagogical laboratory, the Central Police Command and also the Centre of Research of Social Opinion (Kryska, 2014, pp. 209-210).

Wanting to define the present appearing tendencies displayed on social maladjustment of subordinate posts of resocialization for juveniles the author accomplished in April and in May 2015 the research in three educational youth centers, the two types were the resocializational - educational and one was the resocializational - rehabilitation. Research was done on 120 pupils. Deep analysis was done on their medical records (psychiatric), the court, the psychological as well as pedagogical. Interviews were also conducted with managers of the posts, as well as teams of pedagogical - psychological workers of these centers.

The essential aim of the research was to answer the research problem, which was: Is there at present an essential change in the symptoms of social maladjustment among juveniles of educational youth centres and what is it connected to or has there been a change in the character of minors who are directed to these posts?

The accumulated research material demonstrated the appearance of new tendencies in the character of directed pupils to juvenile posts. On the grounds of the posts about $8 \%$ of the pupils were characterized with a high degree of demoralization. These were pupils, who possessed a suspended in time test of being present at a reformative centre or they had a petition about being located in a reformatory institution at the court. These juveniles had sentences of demoralized freedom that were suspended, they had social work or they had notified the case to the police or informed the public prosecutor's office about committing a punishable offence.

A group of $16 \%$ of juveniles were identified as generators of violence on the grounds of the posts, where it was proven to them and consequences were carried out against them for displaying violence towards their colleagues. One can consider them as people who characterise themselves in applying verbal aggression and beyond verbal.

Identification of the population of pupils who displayed special difficulty in adaptation was also accomplished. Juveniles were not able to fit into the reality of these institutions, they were resistant to their stay, they ran away from the centers refusing return to them. These were $17 \%$ of juveniles under care that were researched at the centers.

Three groups of juveniles above were characterized (the pupils having a high degree of demoralization, generators of violence towards others as well as minors who have adaptive problems - who are often victims of violence) 
who did not generate large educational problem on the grounds of the resocialization centers.

A significant percentage of the studied group, up to 33\% required specialist psychiatric care considering the diagnosis of psychotic and psychical disorders. The juveniles had emotional and behavioural disorders, mixed behaviour disorders and emotional, neurotic disorders connected with stress, aspects of psychogenetic as well as schizophrenic disorders.

A large group was made up of pupils that were "harmful" in taking psychoanalytic substances. They were juveniles with diagnosis of mixed dependencies, disorders caused by psychoanalytic substance dependency as well as indications for ambulant therapy. They created a group of almost $40 \%$ of the studied population.

\section{SHORT OVERVIEW}

The dynamics of today's society attracts considerable changes in the functioning of the present youth. This phenomenon is displayed also among juveniles who show different forms of social maladjustment.

The presented study shows, that currently there has taken place a fundamental change in the character of managing educational resocializational posts. Juveniles having psychical and psychiatric disorders as well as minors taking "harmful" psychoanalytic substances are the biggest challenge for the working staff in such posts.. That is why it is necessary to change the applied methods and forms of work in educational care and therapeutics, which must be adapted to the appearing challenges. This is directly linked with the necessity of changes in qualifications and skills of the employed staff at posts as well as the evolution in people working with the present social maladjusted youth. Unfortunately the functioning system of the higher education only in a limited way prepares its graduates for work in such groups with pupils. The majority of the employed pedagogical staff in the past were not suitably educated in this field, because minors with the mentioned disorders did not constitute such a wide problem on the grounds of resocialization institutions. It is necessary therefore to conduct actions in order to change the system of educating the pedagogical staff, which in a wider range will be forced to work with minors that have psychical and psychiatric disorders and are characterized with tendencies of applying different kinds of psychoanalytic substances.

\section{REFERENCES}

[1] Cekiera, Cz. (1979). Pojęcie i formy nieprzystosowania społecznego [The concept and forms of social maladjustment]. Zagadnienia Wychowawcze a Zdrowie Psychiczne, 5. 5-12.

[2] Farrington, D. (2007). Childhood risk factors and risk-facused perspective. In: M. Maguire, R. Morgan, R. \& Reiner (Eds.). The Oxsford Handbook of Criminology (pp. 69-78). New York: OUP Oxford. 
[3] Grzegorzewska, M. (1964). Pedagogika specjalna [Special education]. Warszawa: PIPS.

[4] Jaworska, A. (2008). O nowy paradygmat w wychowaniu młodzieży niedostosowanej społecznie [A new paradigm in the education of socially maladjusted youth]. Opieka Wychowania - Terapia, 3-4. 75-76.

[5] Kelly, J. B. (2000). Children's adjustment In conficetd and divorce: A decade review of research. Journal of the American Academy of Child and Adolescent Psychiatry, 39. 45-53.

[6] Klaus, W. (2009). Dziecko przed sądem. Wymiar sprawiedliwości wobec przestepczości młodszych nieletnich [The child before the court. Justice to the younger juvenile crime]. Warszawa: Wydawnictwa Akademickie i Profesjonalne.

[7] Kryska, S. (2014). Młodzież niedostosowana społecznie kiedyś i dziś - porównanie skali zjawiska i charakterystyka niedostosowania społecznego [Socially unsuited young people then and now - a comparison of the situation and characteristics of social maladjustment]. In: I. Bieńkowska, \& I. Fajfer-Kruczek (Eds.). Resocjalizacja, probacja, praca penitencjarna [Rehabilitation, probation, prison labor] (pp. 205-211). Cieszyn: Wydawnictwo ARKA.

[8] Obwieszczenie Ministra Sprawiedliwości z dnia 25 stycznia 2002 r. w sprawie ogłoszenia jednolitego tekstu ustawy o postępowaniu w sprawach nieletnich [The announcement of the Minister of Justice of January 25, 2002 on the publication of the consolidated text of the act on proceedings in juvenile cases] (2002). Dz. U. [Journal of Laws] 2002.11.109. Retrieved August 17, 2016, from http:/ /isap.sejm.gov.pl/DetailsServlet?id=WDU20020110109.

[9] Paszkiewicz, A. (2012). Moda na agresję - ustawki wśród młodzieży [Mode for aggression riots among young people]. Problemy opiekuńczo-wychowawcze, 10. 155-156.

[10] Pytka, L. (1997). Pedagogika resocjalizacyjna: Wybrane zagadnienia teoretyczne, diagnostyczne $i$ metodyczne [Social Rehabilitation Pedagogy: Selected theoretical, diagnostic and methodical issue]. Warszawa: Wydawnictwo Akademii Pedagogiki Specjalnej.

[11] Rozporządzenie Ministra Edukacji Narodowej z dnia 12 maja 2011 r. w sprawie rodzajów i szczegótowych zasad działania placówek publicznych, warunków pobytu dzieci i młodzieży w tych placówkach oraz wysokości i zasad odpłatności wnoszonej przez rodziców za pobyt ich dzieci w tych placówkach [Regulation of the Minister of National Education of 12 May 2011. On the types and detailed rules of operation of public institutions, the conditions of residence of children and youth in these facilities and the amount and rules of payment paid by parents for their children stay in these facilities] (2011). Dz. U. [Journal of Laws] 2011.109.631. Retrieved August 17, 2016, from http:/ / isap.sejm.gov.pl/DetailsServlet?id=WDU20111090631.

[12] Seligman, M. E. P., Walker, E. F., \& Rosenhan D. L. (2003). Psychopatologia [Psychopathology]. Poznań: Zysk i Spółka.

[13] Ustawa z 26 października 1982 r. o postępowaniu w sprawach nieletnich [The Act of 26 October 1982. Proceedings in juvenile cases] (1982). Dz. U. [Journal of Laws] 1982.35.228. Retrieved August 17, 2016, from http:/ /isap.sejm.gov.pl/DetailsServlet?id=WDU19820350228. 